\title{
An Application and Contribution of Abduldaem Al-Kaheel's Website towards Quranic Learning in the Perspective of Modern Science
}

\author{
Lukman Afandi \\ Universiti Malaya, khulaifat1987@gmail.com \\ Monika@ Munirah Abd Razzak \\ Universiti Malaya,munirahar@um.edu.my \\ DOI: https://doi.org/10.22452/usuluddin.vol47no1.5
}

\begin{abstract}
Abduldaem Al-Kaheel developed his own website that dedicated to emphasizing on learning the Qurān in the perspective of modern science. This article elaborates on his contribution in learning verses of the Qurān that are relevant to science using websites as platforms. The site discusses meaning of the verses that can be interpreted in the perspective of science, and then detailed explanations of the links between the verse and the scientific findings. The article concludes that the appreciation and understanding of the Qurān through internet is an effective way that one could use as self-study or reference to deepen knowledge of the teaching of the Qurān in the perspective of science. This article elaborates on methodology of Quranic interpretation through a scientific approach that focuses in relating certain verses to modern scientific findings.
\end{abstract}

Keywords: computer application, scientific approach, website, the Qurān, science, Abduldaem Al-Kaheel

\section{Introduction}

The Qurān is the last and final revelation book of Allah which was sent to the Prophet Muhammad. It is the main source of knowledge in Islamic faith and teaching that contains guidance for all mankind. The Holy Qurān is a resource, of all knowledge, regardless of past, recent discovery, or even future knowledge, whether it is known or unknown to the public. ${ }^{1}$ The authenticity and preservation of the Qurān is stated in one of its verses, Allah Says:

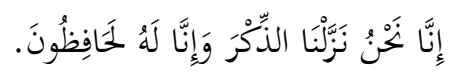

Al-Hijr 15:9

1 Abū Hāmid Muḥammad bin Muḥammad al-Ghazālī, Ihyyā' Ulūm al-Dīn, (Cairo: Dār Al-Thaqāfah al-Islāmiyah, n.d.) 1:301. 
Indeed, it is We who sent down the Qurān and indeed, We will be its Guardian.

The revelation of the Qurān is to address principle issues of humankind and their existence in this world, which covers aqidah, shari' 'ah and akhlāq. However, it is also emphasised for Muslims to discover and reflect. ${ }^{2}$ The discovery of the Qurān is more crucial particularly on verses that discuss on creation of universe, cosmos, earth, human biology, environment and the atmospheres. However, to embark on this discovery, certain set of knowledge in advance science and technology is required for this effort.

The science and technology as defined by religious scholars are not the knowledge that are able to liberate humans from being human. It is rather to guide and explain the objectives of human life, guided by the wahyu of the Qurān. ${ }^{3}$ Hence, it can be considered that science and technology are important tools that help Muslims to explore in depth the meaning of those verses and guide them to understand the reasons behind those creations.

This is because the scientific evidences in the Qurān shows that it is clearly of divine origin. ${ }^{4}$ This also gives strong indication on the importance of inculcation of science as important component in learning and understanding the verses of the Qurān. As it is justifiable study on natural science from the Islamic point of view as recognising the significance of science which has two fundamental reasons: the role of science with the objective of knowing God, and to stabilise and advance Islamic society. ${ }^{5} \mathrm{By}$ combining both learning of the Qurān through conventional Quranic exegesis and its sciences and learning of the Qurān in the perspective of modern science would give greater holistic point of view and impact in understanding the specific verses of the Qurān.

The verses of the Qurān are relevant with modern science and its findings. All Muslim scholars have to master modern science

2 Muhammad Quraish Shihab, Membumikan al-Quran: Fungsi dan Peran Wahyu dalam Kehidupan Masyarakat (Bandung: Penerbitan Mizan, 1994), 35.

3 Baharudin Ahmad, Falsafah Sains dari Perspektif Islam, $2^{\text {nd }}$ ed. (Selangor: Dawama Publication, 2008) 9-10.

4 Syed Muhammad Naquib al-Attas, "Keynote address in the International Seminar on Islamic Philosophy and Science USM" (Penang: Art Printing Works Sdn. Bhd., 1989), 2-3.

5 Mehdi Golshani, The Holy Qurān and the Sciences of Nature (Tehran: Islamic Propagation Organisation, 1986) 47-48. 
for them to explain the teachings of the Qurān more profoundly, as supported by scientific findings. ${ }^{6}$ There are various Muslim scholars who have discussed science in the Qurān, there are verses explaining facts about the universe, earth, geology, chemistry, animals, plants and the human body, in a scientific and systematic manner. Hence, this indicates that Allah indirectly teaches humans to think scientifically. The fact of the verses of the Qur'ān can be proven scientifically, for example of the body of Pharaoh which Allah promised to preserve his body as stated in Sürah Yünus verse 92, Allah Says:

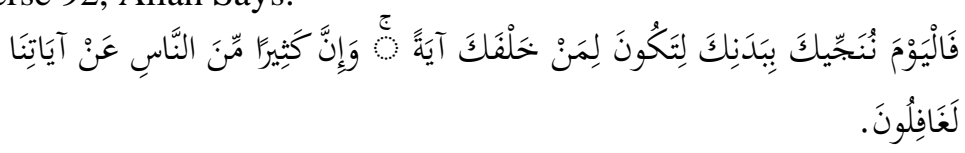

Yūnus 10:92

So today, We will save you in body that you may be to those who succeed you a sign. And indeed, many among the people, of our signs, are heedless.

Any individual who studies in depth of the above verse would find it full of scientific facts, ${ }^{7}$ It was discovered that the Quran has mentioned this finding 1400 years ago. ${ }^{8}$ The scientist found that the surface of the Pharaoh's body contains mixing of salt together with element of other chemicals. This gives some indication to the cause of death that is being concluded that it was drown in the sea. While other effect of chemicals in the body shows that the it has gone through mummification process that to prevent it from decompose. The process of preservation will retain the body condition intact in one piece and could lasting beyond centuries. Hence, the important aspect of understanding the Qurān in the perspective of science is through application and observation.

Through observation, one can understand the truth, as both the Qurān and science use the same method. It is an instruction by

6 Syekh Thantāwi Jauhari, Al- Qur'an dan llmu Pengetahuan Moden, trans. Muhammadiyah Jaafar (Surabaya: Usana Offset Printing, 1984) 26-29.

7 Fadhil Haji Othman, Pendidikan Sains dan Teknologi dan Alam Sekitar Menurut Pandangan Islam (Kuala Lumpur: Syeikh Publisher, 1992) 61-66.

8 Bucaile, M., "The Quran and the Modern Science" in Mohammad Ilyas, The Unity of Science and Religion (2002), p. 49-68. 
Allah for man to tadabbur. ${ }^{9}$ However, to apply this method, one should equip himself first with certain set of knowledge of both conventional Quranic exegesis studies and science. Without which, the method would not be effective.

In discussing science in the Qurān, it is of the view that the salient scientific challenge of the Qurān is the challenge to humans and jinn to bring forth similar verses as the Qurān which is unanswered until now. Hence, the application of modern science that inculcated in the learning of the Qurān must have clear objective.

The scientific exegesis of the Qurān can be considered as a new approach in explaining the meaning of the Quranic verses that supported by modern scientific findings. The approach can play an important role to discover the hidden secrets of the Quran found through advance science research that able to shape a new perspective of the world view. ${ }^{10}$ It can be used as an effective tool to understand in depth the meaning of the Qurān in discussing certain verses related to the creation of the universe, human being and other creatures. Those who do not learn science will face difficulty to appreciate and understand in depth verses that requires certain set of knowledge in science such as verses on embryology and function of brain.

\section{Development of Information Technology}

The usage of ICT in lectures or workshops can give greater impact to the audience as a list of Islamic websites on Quranic studies and interpretation is available and can be applied in Quranic teaching classes. ${ }^{11}$ The impact and benefit of using Information and Communication Technology (ICT) in the Islamic world is great, the use of online Islamic references in the materials for religious classes might be useful and facilitate the needs of speakers and lecturers.

9 Sirajudin Zar, Konsep Penciptaan Alam dalam Pemikiran Islam, Sains dan alQurān (Master's Dissertation, IAIN Syarif Hidayatullah Jakarta, 1997) 38-46.

10 Selamat Amir, "Pentafsiran Saintifik dalam Al-Quran: Satu Pengenalan Terhadap Metode Al-Sha'rawī dalam Tafsīr Al-Sha 'rawī, Tumpuan Surah AlAn'am ayat 12," Jurnal Usuluddin 42 (2015): 72.

11 Ahmad Zulfiqar Shah Abdul Hadi, Sistem Pengajian al-Quran Kontemporari: Kajian Aplikasi Teknologi Maklumat dan Komunikasi (Master's Dissertation, Academy of Islamic Studies, University of Malaya, 2006). 49-50. 
The usage of ICT develops creativity and provides widerange of new teaching skills. It is part and parcel of attracting interest towards the subjects. Nevertheless, not all Quranic studies could be effectively delivered hundred percent in ICT and superseded the conventional teaching due to its nature of teaching and learning process. For instance, learning Quranic recitation with proper tajwid and tarannum. The learning requires close monitoring in auditory to ensure words are pronounced correctly based on its procedures. Nevertheless, there are ways to combine element of interactive in the learning process while maintaining the conventional way of teaching, it can be embarked through combination of both approaches, which is called blended-learning, which retain conventional learning process in some part and use ICT as a platform in the other part.

The Internet is a product of technology and whose primary objective is to facilitate and to ease the work of humans. Any product of technology used with good intentions to serve the ummah can give positive results. ${ }^{12}$ In this regard, learning Islamic and Quranic studies through internet website is really encouraged provided one have proper background of having certain level of Islamic knowledge that able to guide him facing different point of views and orientation of religious thinking on articles found in the website.

The usage of proper on-line Islamic materials as references and using multimedia as part of the approach will contribute to delivering dakwah effectively. ${ }^{13}$ Nevertheless, having certain level of knowledge of intra-faith and deep understanding of variety of Islamic doctrines and orientations, might help to increase level of awareness and prevention, at the same time, reduce the percentage for being influenced by Islamic extremist ideology and thus, potential for being self-radicalisation could be avoided.

The world is already entering the fifth phase of human civilisation, where ICT will become the main agenda in economy and development. Hence, Muslims should take the opportunity to

12 Sidek Baba, "The Muslim Nation Agenda: the Challenges of Information Technology and Internet" (Seminar Prosiding, Institut Kefahaman Islam, 1998) 12.

13 Abu Bakar Abdul Majeed and Siti Fatimah Abdul Rahman, Multimedia dan Islam (Kuala Lumpur: Institut Kefahaman Islam Malaysia, 2001), 9-10. 
fully use these for the purposes of spreading Islam. ${ }^{14}$ Prior utilising the internet in spreading Islam, it is encouraged that one should have sufficient content of Islamic knowledge, understand contextualisation and contemporary issues and equipped with skills in countering different opinions.

\section{Qurān and Development of ICT}

The development of a database for Tafsìr al-Qurān might contribute to understand on the extent learning the Qurān can be embarked among Muslim community. ${ }^{15}$ The advanced development of ICT has eased communication and access to information. For instance, one only needs to use a search engine to search for a topic or keyword. ICT is used by individuals, groups and organisations to propagate their orientations, information and knowledge. From a positive perspective, it is also being used as a platform for propagating Islam and making research in Quranic studies globally accessible. In fact, it was being utilised in religious education.

There was a survey conducted on the usage of on-line Tafsir among teachers of Bestari School at Kolej Sultan Alam Shah, Kelang of which, the finding shows that it is a meaningful method for both teachers and students. ${ }^{16}$ Meaningful in a sense of it helps to expedite in findings teaching materials and references and at the same time could contribute for the lessons to be more interactive. The contribution could be in the sense of providing sources on reading materials and references which can be easily downloaded from the Islamic websites that offer accessibility to the materials. By having these facilities, the ICT will play a greater role as source of knowledge as compared to the conventional role played

14 Makhdir Mardan, "Mendaki Zaman Perubahan yang berterusan" in Memahami Islam melalui Teknoloji Maklumat dan Komunikasi, ed. Sh. Mohd Saifuddeen Sh. Mohd Salleh (Kuala Lumpur: Institut Kefahaman Islam, 2000), 18-19.

15 Abdullah Bukhari, The Modernisation of Teaching Tafsir al-Quran among Malays: An Analysis of Development of Data for Tafsir al-QurAn, (Academic exercise paper, Academy of Islamic Studies, University of Malaya, 2004),36.

16 Norharliayana Hamdzani, Teaching Tafsir Al-Qurān via Internet: Survey on the Usage of On-line Tafsir among Teachers of Bestari School at Kolej Sultan Alam Shah, Kelang (Academic exercise paper, Faculty of Social Science, Islamic Studies Program,, University of Malaya 2001), 43. 
by the library as main source of providing books, references and reading materials. This could be happened through digitization and digitalisation process of the reading materials. In fact, through this facility that offered by the ICT, it will affect conventional teaching and learning process of the Quranic studies, be it in schools or in tertiary institutions. Hence, a traditional way of teaching approach would have to slowly adjust to inculcate this technology as part of the teaching and learning approach.

There are different methods available on the Internet to learn Quranic sciences. For example, readings from renowned reciters in audio format, different recitation techniques (qira $\bar{a} t$ ), translation into various languages, lists of books about tafsir and $\square U l u ̈ m ~ A l$ Qurān that are available in PDF format can all be found online. This includes websites on I'jäz Qurān and scientific Quranic interpretations. Among those sites that offer learning of the Quranic Sciences for instance to study the Qurān that include recitation, Tafsìr, books related to Al-Quran and general information about the Qurān. There are hundreds of websites that provide learning Quranic sciences. This study listed some of those websites that come with brief descriptions particularly on Quranic Sciences, on-line learning the Qurān and Tajwìd, Tafsìr al-Qurān and Learning the Qurān in the perspective of modern science.

\section{Quranic Sciences}

The study found that websites, which provide content that emphasize on Quranic Sciences offer different weightage of information and services. Generally, the similarity of those websites provided basic navigation tools of the Qurān particularly on Quranic texts, recitation and translation. The websites that provides basic navigation tools of the Qurān such as At-Tanzil http://www.tanzil.net ${ }^{17}$.

There are other websites that provides additional features of navigation tools, information and services such as website of alMaktabah al-Waqfiya http://www.waqfeya.com ${ }^{18}$. Besides providing navigation tools on the Qurān, the website offers variety of Islamic books such as tafsīr, "ulüm al-Qurān, Hadīth, Fiqh from different mazhab, usūl figh, comparative jurisprudence,

17 At-Tanzīl, http://www.tanzil.net - retrieved on 6/8/2014.

18 Waqfeya, http://www.waqfeya.com - Retrieved on 12/8/2014. 
comparative religions and Islamic ethics. All the books offered are available in PDF format. In addition of offering Quranic Sciences, other websites such as Islamic encyclopedia http://www.islamicencyclopaedia.org/ ${ }^{19}$, offers an encyclopedia of Islamic terminologies including names of well-known scholars from the era of the Prophet Muhammad (pbuh) up to this century, list of Hadīth from the books of Sahīh Bukhārī, Sahịh Muslim, alMuwattāa' Ibn Mālik and a collection of fabricated or weak Hadìth.

Lastly, there are other websites that developed to educate the public on the true message and wisdom of Islam, for Muslims and non-Muslims such as http://www.iqrasense.com/subscribe ${ }^{20}$. The website offers Islamic books, Islamic products and Quranic studies.

All the above websites are very useful for those who embark on research or teaching religious subjects to find additional Islamic references. Those websites could be considered as 'on-line library' as so many resources of classical texts of Islamic scholars can be found in it. The resource materials are mostly in Arabic text. Hence, those who are not well-verse in the language requires guidance in selecting those reading materials.

\section{Online Learning the Qurān and Tajwīd}

Basically, websites that offer online learning of the Qurān and Tajwīd provide similar package of services that are learning of recitation and memorisation of the Qurān for children and adults in different levels or modules and methodologies.

However, each website provides additional services such as website of the Qurān and Science http://quranicsciences.org ${ }^{21}$. This website is owned by Institute of Quranic Sciences (IQS), a non-profit organisation based in USA with the objective of initiating different programmes for teaching and understanding the Quran and promoting authentic Islamic knowledge. The website offers online learning of Quran for both children and adults throughout the week. It also offers services such as memorisation for kids, translation and interpretation for adults, basic Islamic

19 Islamic encyclopaedia http://www.islamicencyclopaedia.org/.- Retrieved on $12 / 8 / 2014$.

${ }^{20}$ Iqrā' Sense, http://www.iqrasense.com- Retrieved on 28/7/2018.

21 Qurān and Science, http://quranicsciencesciences.org retrieved on 3/9/2014. 
teachings, Arabic and Urdu language learning, interfaith dialogues and comparative religions for adults. The website requires registration for participation. Generally, the website main's function is providing online Quranic education services particularly recitation and memorisation of the Qurān for children and adults. Other stated programs could be considered secondary as it is not provided details information on content syllabus and methodologies used particularly interfaith and comparative religions programs.

Website such as http://www.qsi1.com/index.asp ${ }^{22}$. This website is owned by Quranic Sciences Institute, dedicated to the late Sheikh Mohammed Manzoor Khan. The website provides online Quranic classes for beginners and advanced students. The curriculum has five levels for teaching. Level one starts from scratch using Nürāni methodology, level two is brushing up using phonetics methodology, level three is learn rules through tajwid, level four is reading and memorising using software and level five uses the Mushaf Madina Style. In addition, the website also provides basic knowledge about prayers, daily supplications, facts about Islam and basic knowledge about mahram and 40 Hadith Qudsī. E-mail signup is required to access the content. The website encompasses only online class on recitation of the Qurān as its main function. The feature of the front page of the website is less attractive as there is used only a green colour for the background and the content used.

Website of Easy Qurān http://www.easyquran.com/ar/pre page-ar.htm ${ }^{23}$. This website is owned by Subhī Țaha and promotes a digital Qurān with colour-coded tajweed hukum. This Quran is approved by Supreme Quranic Committee of Egypt. The digital Quran comes in pocket-size and tablet. The website explains its features such as colour coding, interactive tests, browsing, transliteration and learning aids. It also mentions the four historical stages of writing the Quran: the first stage was the calligraphy of the Quranic words, the second stage was calligraphy and vowel during the era of Sayyidina 'Alī bin Abī Tâlib r.a the

${ }^{22}$ Quranic Science Institute, http://www.qsi1.com/index.asp - Retrieved on 10/9/2014.

23 Easy Qurān, http://www.easyquran.com/ar/prepage-ar.htm - Retrieved on $10 / 9 / 2014$. 
third stage was calligraphy, vowel and dotting during the Umayyad age in the era of 'Abdul Mālik bin Marwān and the final fourth stage was calligraphy, vowels, dotting and tajwìd. The website provides its niche area of learning the Qurān through digital technology. Offering calligraphy and vowelisation from the era of the companion is a rare service provided by the website owner. The medium of the website used is both English and Arabic language. The buttons to browse further information located in all area of the website with different shapes and sizes without providing any pictures.

Website of Qurān Reading http://www.quranreading.com /about-us ${ }^{25}$. This online school offers online Quranic reading classes based in Maryland, USA. The providers of the website believe that the process of learning Quran must be as simple and facilitative as possible. The online classes provided are: Quran reading, translation, recitation and memorisation. The classes are conducted using Skype and GoToMeeting applications. In addition, the website offers free MP3 downloads of recitation and translations for Android and iPhone. Learning the Qurān via skype application is one of the features of this website. The effectiveness of the run of the Quranic class through this application relies on how fast the speed of the internet of that area and the trained teachers.

Website of Learning Qurān Online http://learningquranonline .com/about-us $/{ }^{26}$. This website offers online learning and over 5000 students have participated in the programmes, with over 600 current students. It offers three types of online classes: as nazra, qaida and memorisation with tajweed. The website also provides free downloadable articles such as 'Disease of the hearts', 'Essentials of Ramadhan', 'See what is life and death', 'Tafsir by Ibn Kathir', and 'Quran with English Translation'.

Other related websites in studying the Qurān with specific information provided are available such as websites for learning

${ }^{24}$ Qurān Reading http://www.quranreading.com/about-us - Retrieved on 17 September 2014.

25 Qurān Reading http://www.quranreading.com/about-us - Retrieved on 17 September 2014.

${ }^{26}$ Learning Qurān Online, http://learningquranonline.com/about-us/ - Retrieved on 17 September 2014. 
variety of recitation of Al-Qurān that covers ten methods of recitation http://www.islamweb.net/ ${ }^{27}$ and http://www.holyquran $. n e t /{ }^{28}$. To find list of reciters of the Qurān in the website: http://www.alijaber.net/ $/{ }^{29}$. To find list of Quranic medication in the website: http://www.alroqia.com. ${ }^{30}$ To find the Translation of the Holy Qurān website: http://www.theholyquran.org/ ${ }^{31}$. To find the Quranic Recitation techniques in the website: http://www.tarteel.com/.$^{32}$ To find list of Quranic Academy and Institutions in the website: http://www.quran.gov.ae $/^{33}$. To find website on Audio Al-Qurān: http://www.islamway.com/. ${ }^{34}$ To find Quranic Interpretation in the website: http://www.tafsir.net/. ${ }^{35}$ To find on studies of Al-Qurān and Science website: http://www.kaheel7.com ${ }^{36}$. and http://www.elnaggarzr.com/en.

The demand of studying on-line learning of the Quran and Tajwīd is increasing nowadays. The number of online providers offering such services manifest the eagerness of the Muslims to turn back to their religion and understand it by learning the Quran. There is a possibility of increasing online learning of the Quran and Tajwīd is because of time constraint as some of them are working adults work for a long-hours and have difficulties to arrange schedules attending religious classes at nearby mosques or Islamic centres. In this regard, to have a perspective of having more online religious learning of the Quran and Tajwīd to cater for those group of Muslims is commendable because it helps to ease them to learn the Quran at their own time without affecting much in adjusting their daily life.

27 Islam Web, http://www.islamweb.net/ - Retrieved on 26/7/2018.

28 The Holy Qurān, http://www.holyquran.net - Retrieved on 26/7/2018.

Shaykh Ali Jaber, http://www.alijaber.net - Retrieved on 26/7/2018.

Al-Roqyah, http://www.alroqia.com. - Retrieved on 26/7/2018.

1 Qurān Translation, http://www.theholyquran.org. - Retrieved on 26/7/2018.

32 At-Tarteel, http://www.tarteel.com http://www.tarteel.com. - Retrieved on 26/7/2018.

33 The Qurān, http://www.quran.gov.ae/ - Retrieved on 26/7/2018.

34 Islam Way, http://www.islamway.com/- Retrieved on 26/7/2018.

35 Tafsīr, http://www.tafsir.net/- Retrieved on 26/7/2018.

36 Al-Kaheel, http://www.kaheel7.com- Retrieved on 26/7/2018. 


\section{Tafsīr al-Qurān}

For Tafsīr al-Qurān, services offered basically on Quranic commentary (Tafsir $)$, translation and recitation of the well-known reciters. However, different websites offer different books of Tafsīr as their main references with additional navigation tools. For instance, website that owned by the Royal 'Aal al-Bayt Institute of Islamic Thought, Jordan http://www.altafsir.com ${ }^{37}$ provides various tafsìr from different school of Islamic jurisprudence and orientations such as Tafsìr al-Jalālayn, Tanwīr Miqbās min Tafsīr Ibn Abbās, Tafsīr al-Tustāri, Tafsīr Kashāni, Tafsīr al-Qusyairī, and Tafsīr Kashf al-Asrār. The Qurān Website http://quranwebsite.com ${ }^{38}$ provides Tafsìr in PDF format includes Tafsīr Ibn Kathīr, Tafsīr al-Jalālayn, Tanwìr Miqbās min Tafsīr Ibn 'Abbās, Tafsīr al-Tustāri by 'Abdullah Al-Tustāri, Tafsìr 'Abd Razzāk al-Kashāni, Tafsīr al-Qusyairī, Tafsīr Kashf al-Asrār wa Uddāt al-Abrār by Rashīd al-Dīn Maybūdī. For MP3 audio format, the website provides tafsir classes conducted by Mufti Menk, Noumān 'Alī Khan, Zākir Naik, Bilāl Philips, Yāsir Qādhi and other scholars from Indo-Pak region. The QTafsīr website http://qtafsir.com ${ }^{39}$ owned by Yūsuf Estes, features a search function of the verses of the Qurān and translations in simple English by selecting the chapter and verse is catered to Englishspeaking Muslims and non-Muslims. The Tafsīr website http://www.tafsir.net ${ }^{40}$, owned by Markaz At- Tafsīr li al-Dirāsāt Al-Qur'ānia, Riyadh, Saudi Arabia, produces an Encyclopaedia of Tafsīr Mawḍ̄ 'ī and other tafsir-related books such as The Quranic Interpreters from the Companions of the Prophet (pbuh), the followers of the Companions of the Prophet (pbuh) (tabieen) and many other books on Usūl Tafsìr. It also provides a Tafsīr Academy for those who want to study the Qurān at the centre. The Al-Islam website http://www.al-islam.com/ ${ }^{42}$, owned by the Ministry of Islamic Affairs, Waqf and Dakwah, Saudi Arabia,

37 The Royal 'Aal al-Bayt Institute of Islamic Thought, Jordan http://www.altafsir.com- retrieved on 5/4/2014.

38 Qurān website, http://quranwebsite.com - Retrieved on 5/4/2014.

39 Tafsīr Qurān, http://qtafsir.com retrieved on 5/4/2014.

40 Tafsīr Qurān, http://www.tafsir.net - Retrieved on 14/6/2014.

41 Al-Islām, http://www.al-islam.com/arb/ Retrieved on 15 June 2014.

42 Al-Islām, http://www.al-islam.com/arb/ Retrieved on 15 June 2014. 
offers the encyclopaedia of Tafsīr and Hadīth. The Quran Complex http://www.qurancomplex.gov.sa/ ${ }^{43}$ owned by Majma' Al-Malik Fahd littibā'a Al-Mushaf Al-Syarîf, offers history of the Qurān that covers the history of compilation and writing of the Qurān, photos of old mushhaf from various periods of Islamic history and photos of decoration and geometric design used in the Qurān. Lastly, website of Islamic awareness http://www.islamicawareness.org/Quran/TafseerTafsir/Ulum $/{ }^{45}$, provides Islamic resources particularly in the areas of Quranic studies, hadith, Islamic history and comparative religions.

Service providers of the Tafsīr Al-Qurān websites offered a wide-spectrum of Quranic interpretation. In fact, some providers use the terminology of Tafsìr al-Qurān loosely which is actually not an interpretation of the Quranic text but it is just a translation to other language such as English to help those who do not know the Arabic language to read the text. On the other hand, some websites go beyond extra miles by not only offer eBook or PDF format of Tafsīr Al-Qurān by scholars, but also offer audio format lectures of well-known scholars discussing on Interpretation of verses of the Quran, Islamic Jurisprudence and also religious views. While this noble effort helps Muslims to increase their information and knowledge about Islam, they have also to be open-minded on certain points of what being preached by those scholars. Perhaps some religious views discussed by those scholars are to address issues pertaining to some religious matters happened in their country which they have better understanding and offer religious solutions that are suitable for their context, but it is not necessarily suitable for the local context. Hence, they have to consider to have an open discussion and to get second views with local scholars on that particular topics that they have listened from the foreign scholars.

43 Qurān Complex, http://www.qurancomplex.gov.sa Retrieved on 16 June 2014.

44 Islamic Awareness http://www.islamic-awareness.org/Quran/TafseerTafsir /Ulum/ - Retrieved on 26 August 2014.

45 Islamic Awareness http://www.islamic-awareness.org/Quran/TafseerTafsir /Ulum/ - Retrieved on 26 August 2014. 


\section{Studying the Qurān in the Perspective of Science}

There is no doubt that there is an indication of link between the Qurān and Science particularly on verses describing on life on earth, the stars and planets. ${ }^{46}$ However, the concept of science in Islamic perspective, is totally different with what is being practised by the West. Islam does not reject science. Instead, Islam has given space to scientists to research and to find the truth. This is because the concept of science in Islam is based on aqidah, which closely follows the principles of the Qurān. Science, in Islam, requires wahyu as its main source.

\section{Online Learning of the Qurān and Science}

There are many websites that discuss the study of the Qurān. However, few sites emphasise in focusing the Qurān and science concurrently. Such site is by Abduldaem Al-Kaheel, http://kaheel7.com ${ }^{47}$ which discuss the scientific contents of Quranic verses and hadith of the Prophet (pbuh). Rationale behind the study of the website is it emphasizes the learning of the Qurān in the perspective of science without discussing any other Quranic sciences. In other word, the interest is very focus in studying the Qurān an Science in depth. This study suggests that Al-Kaheel does not only focus on developing website on the Qurān and science. In fact, he also produced many books, articles and TV interviews in Arab countries discussing various topics related to Qurān and science. This article focuses on his usage of website as a platform for that purposes.

\section{Background of Al-Kaheel's Website}

The Qurān is not only a book revealed by Allah to the Prophet (pbuh), like the other books or suhuf revealed to previous prophets. Prophet Dawood (alaihissalam) was given the Psalms, Prophet Moses (as) was given the Torah and Jesus (as), the Gospel. In addition to these books, they were also granted community-specific miracles. For example, Prophet Moses was given a stick that turned into a serpent, in line with his people's

${ }^{46}$ Faizah Mat Juden, Teori Kewujudan Alam: Satu Kajian Perbandingan di antara Sains Moden dan al-Qurān (Master's Dissertation, Academy of Islamic Studies, University Malaya, 2003) 57-58.

47 Al-Kaheel, http://kahof eel7.com - Retrieved on 27 July 2018. 
belief in and practice of black magic. Jesus (as) was given the miracle of curing diseases such as blindness - compatible with the practice of applying medical science. Prophet Muhammad (pbuh) was given the Qurān, considered a miracle in and of itself because his people - the Arabs - were famous for poetry and exalted other literary cultures that used beautiful Arabic. However, despite being experts in the study of the Arabic language, they were unable to write in a style like the verses in the Qurān. These verses are not only grammatically perfect, but also contain messages dazzling even those who are experts in the language. The miracle of the Qurān may not only be described in terms of the beauty of the language, but also with its message about the universe and human beings.

This observation is shared by Al-Kaheel. For him, despite being an engineer by profession, he is more inclined to contribute to Muslims' understanding and appreciation of the content of the Qurān, particularly verses that emphasise the exploration of the creation of the universe and human life. the aim of developing his website was to deepen the belief in Allah, the glorious Qurān and their Prophet (pbuh) by looking at scientific facts that align with the Qurān and hadith of the Prophet (pbuh). He also aims to encourage Muslims to explore the scientific notions behind certain verses of the Qurān.

\section{Assessment of Al-Kaheel's Website}

This study focuses on websites developed by Al-Kaheel (http://kaheel7.com) ${ }^{48}$ on Quranic studies and science. This study assesses the following points:

1. Background information of author.

2. Objectives of website.

3. Medium of instruction.

4. Examples of application of the learning of the Qurān in the perspective of modern science.

5. Contribution of Al-Kaheel in the field of learning of the Qurān in the perspective of modern science.

48 Al-Kaheel, http://kaheel7.com - Retrieved on 27 July 2018. 


\section{Background information}

Born in Homs, Syria in 1966, Abduldaem Al-Kaheel researches scientific miracles in the Qurān and Sunnah. After graduating in mechanical engineering from the University of Damascus in 1995, he obtained a diploma in education and engineering in 1998. Fluent in Arabic and English, he is currently based in Cairo, working as a researcher at the International Agency for Quranic and Hadith Research Authority. He also actively participates in seminars, TV programmes and international conferences in Kuwait, Turkey, Spain, Dubai, Morocco and Algeria. His latest publication is a book on the digital system of number seven in the Qurān. Through his education background, Al-Kaheel did not receive formal religious education. However, he has strong inclination in studying verses of the Qurān and have a strong missionary zeal to have other fellow Muslims to understand the verses of the Qurān.

\section{Objectives of his website}

The objectives of Al-Kaheel's website are to:

1. Leverage dialogue on issues related to Al-Qurān and science.

2. Promote holistic Islamic teaching integrated with science.

3. Prove that science has a role to play in understanding verses of the Qurān.

4. Promote teaching and learning of the Qurān and hadith of Prophet Muhammad (pbuh) through the perspective of science.

5. Encourage Muslims to deepen their knowledge in science, as it is a tool to understand the Qurān, particularly the verses that discuss the creation of the universe.

6. Prove that scientific findings can help to elaborate in detail the true meaning of Qurān and hadith as revealed 1400 years ago, which was not being understood then.

7. Science as evidence for those who doubt the Qurān as being Allah's words.

8. Promote greater sharing of the topics pertaining to Qurān and science.

Through the list of the objectives, it shows that he has a noble effort in promoting a different way of learning the Quran from the traditional approach. The approach that he suggested is to learn the Quran through integration of science. However, the suggested 
approach could be more understood if it can be translated and elaborated into a holistic concept of Quranic learning framework, in which a comprehensive Quranic learning curriculum can be developed. The objectives should come with suggested learning skills that help Muslims to understand and appreciate the integration concept of science with the Quran. Secondly, to help Muslim to understand the concept of learning the Quran in the perspective of modern science, it requires certain set of criteria as a guidance to embark to the process of the scientific interpretation, without which, possibility of falling into wrong interpretation of the verses can be easily occurred.

\section{Medium of instruction}

Al-Kaheel develops and monitors his website, which is dedicated to Muslims and non-Muslims in all countries. It provides translations to English, French, Persian, Indonesian, Dutch, Turkish, Russian, Kurdish, Japanese, Spanish and Hebrew. Through translation to varieties of languages, the website can attract visitors from multi-lingual nationalities to access the content and appreciate the learning of the Qurān that he promoted.

\section{Criteria framework used for the analysis}

This study will use a criteria framework as a guide to analyse on to what extent the interpretation of the Qurān in the perspective of science follow closely the criteria. For the field of scientific interpretation of the Qurān, Al-Zindānī's methodology could be considered as a guide. ${ }^{49}$ Hence, analysis of this study, will use criteria suggested by Al-Zindāni: ${ }^{50}$ i) The sources should be based from the Qurān and the hadith of the Prophet pbuh under strongest categories which is either Sahīh or Hasan ii) The scientific facts used should be from credible and reliable sources that based on experiments. Scientific hypothesis and theories would not be accepted as credible sources until it is being tested and proven iii) Research embarked should be in-line with scientific miracles (I'jāz

49 Tazli Sham Abd Rahman, "Contrbution of Syakh Abd Al- Maj̄̄d Al- Zindān̄̄ to Al-I'jaz Al-'Ilmi”" in Online Journal of Research of Islamic Studies, No.2. (2014) 54-55.

50 Al-Zindān̄̄, 'Abd al-Maj̄̄d bin 'Azīz, Ta'sil al-I'jaz, al-'Ilmi, http://www .jameataleman.org/mai - Retrieved on 4 May 2015. 
Ilmī) methodology and guidelines iv) The scientific findings is discovered based on latest technology which is very unlikely to be found in the time of the Prophet pbuh during the revelation of the Qurān as such technology is yet to be developed .

\section{Examples of Application of the Learning of the Qurān in the Perspective of Modern Science by Al-Kaheel}

This study brings some articles from various topics discussed from Al-Kaheel's website and to do the analysis that based on the above criteria.

\section{Washing Hand as Part of Cleanliness}

In discussing about cleanliness through washing hand, Al-Kaheel brings verse 6 of Surah Al-Māidah. Allah says:

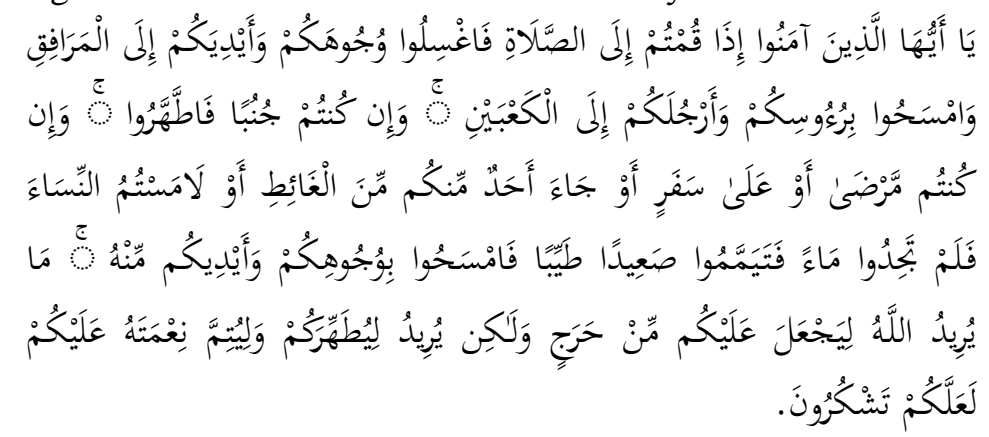

Al-Mā'idah 5:6

O you who believed, when you rise to (perform) prayer, wash your faces and your forearms to the elbows and wipe over your heads and wash your feet to the ankles. And if you are in a state of janābah, then purify yourselves. But if you are ill or on a journey or one of you comes from the place of relieving himself or you have contacted women and do not find water, then seek clean earth and wipe over your faces and hands with it. Allah does not intend to make difficulty for you, but He intends to purify you and complete His favour upon that you may be grateful.

In discussing topic about washing hands and cleanliness, his style and approach where he uses it in his website that is to discuss on the topic that he chooses first, then he brings some evidence from scientific findings by scholars or institutions. In this regard, 
his article stresses that by taking a habit of washing hand after visiting washroom will reduce a possibility of infected with various bacteria diseases. He mentioned some research findings carried out by British study shows that some diseases such as influenza caused by $\mathrm{H} 5 \mathrm{~N} 1$, severe acute respiratory syndrome (SARS) and even pneumonia are infection that shows link to personal and environmental hygiene and infection. Based on the study, a potential possibility to reduce those diseases to spread out is through a habit of handwashing as frequent as possible particularly after every visit of public restrooms. Through the habit, diseases could be controlled from spread. Another finding of result of good habit of handwashing as mentioned in his website, it can reduce infection of diarrhoea by one-third. This could be done by washing hand with soap by a minimum of twenty second.

Through this habit of cleanliness, Al-Kaheel attempts to relates it with verse 6 of Surah Al-Māidah which describes generally some Hukum of Fiqh that pertains to cleanliness on certain circumstances, particularly on preparation of Saläh one should follow proper method of ablution as mentioned in the verse. In the event when the person is in janäbah, one should take a shower first. In the circumstances where a person fell sick, or in travelling, or after relieve himself or have touched women but could not find any source of water, then one should perform a Tayammum as an alternative ritual of ablution that is to rub dust on face and hand.

Through this topic, Al-Kaheel tries to highlight a significant of being in state of cleanliness taught by our religion that is a compulsory shower after janābah, take ablution (wudu') prior performing prayer (solāh) or perform a tayammum as part of ritual cleaning using dust representing ablution ( $\left.w u d \bar{u}^{\prime}\right)$ in the event one could not find a source of water. The ablution (wudu'), compulsory shower and tayammum are religious rituals that every single Muslims should know how to perform it. Through these rituals Islam actually teaches congregant for always being in a stage of cleanliness, in any circumstances and situations. Even though it did not explain in detail its significant in the perspective of sciences, but taking cleanliness as a habit is actually part and parcel of prevention for being infected by various diseases. This is the message that Al-Kaheel tries to explain in his article on 
cleanliness and handwashing. Despite not being told on significant of that rituals, which Muslim are asked to prevail it prior performing their prayer (salāh), latest scientific findings show that by prevailing those rituals contributes in reducing the effect of being infected of various diseases. The article is very important to show how Islamic rituals are aligned with scientific findings despite Muslim who live in pass eras did not know the significant in the perspective of science of those rituals.

Secondly, he describes the topic of cleanliness and hand washing is rooted with teaching of Islamic practices, in addition, he brings a hadith of prophet SAW. In the Hadith, prophet SAW. gives an analogy of it there is a river flows in front of a person's house and he showers in it five times a day, that is suffice for him for being in a state of hygiene and cleanliness throughout the day. Similar to those who perform prayer (ṣolāh) five times a day, as it will purify his body and soul. The content of the above hadith, which is actually describing a purification of body and soul could be gained through performing prayers (șolāh) five times a day. However, Al-Kaheel uses it in the perspective of being hygiene and cleanliness because it is understandable that a Muslims would have to take ablution as compulsory part of rituals prior performing any prayers (șolāh).

In commenting the verse in the perspective of science, AlKaheel brings results of scientific experiments carried out the British and American Health Institutions on hygiene and cleanliness that supported his point of view. He also quoted the hadith of the prophet SAW. about the ablution. However, in his article, neither he mentions the narrators of hadith among the companions (Sahäbah) nor indicating the category of the hadith. It is only mentioned that it was narrated by Al-Bukhari and Muslim. It has been analysed of the authenticity of the hadith used for the topic and found that the hadith is narrated by Imam Bukhari in his Sahih under the title: Times of the prayers, Chapter: The five prayers (Solāh) are expiations of sins. The Sahabah who narrated it was Abū Huraira r.a. The hadith is also narrated by Imam Muslim in Sahīh Muslim under the title of "The Book of Mosques and Places of Prayer" and it categorised as Sahīh. The Sahabah who narrated it was QutaYbah bin Sa'īd r.a. In this regard, AlKaheel is seen stick to apply a standard of criteria set for using a 
Sahì category of hadith in his article, which is acceptable and follow the guidelines of references in the perspective of science.

\section{Consumption of Moderate Amount of Food Increase the Memory}

In discussing about consuming food moderately, Al-Kaheel elaborates on the way Allah commands His servants to consume foods and drinks that He provided based on proper diet without excessive which could lead to wastage of foods. In this regard, he quotes verse 31 from Surah Al-A'raf, Allah says:

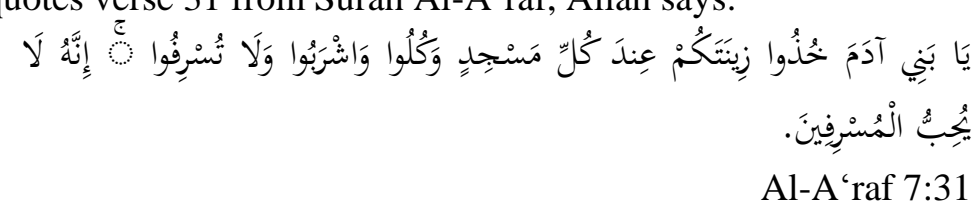

$\mathrm{O}$ children of Adam take your adornment at every masjid and eat and drink but be not excessive. Indeed, He likes not those who commit excess.

Al-Kaheel of the view that by following commands from Allah through this verse help one to balance individual dietary system that contribute to a healthy lifestyle and increase memory system. He bases his view with scientific finding carry out by a group of researchers from University of Munster, Germany, headed by Dr Veronica Witt on food nutrition. The nature of study was to observe various groups of research participants who were asked to consume certain quantity and quality of foods in different portion of nutrition for a duration of about three months targeting around fifty overweight men and women whom their average age was around sixty years old. They were divided in to three groups with specific dietary. A 30\% calorie restricted types of food were imposed for Group A, A non-saturated fats such as fish and olive oil were imposed to Group B, and no specific and restricted diet for Group $\mathrm{C}$ as the control group. After the period of research completed, it shows that Group A have exhibited tremendous improvement in their memory test and showed their ability in memorising words. Whereas Group B and C did not show any improvement in their memory.

Al-Kaheel tries to explain this verse in the perspective of science by connecting a moderate eating with taken less calories and balance with proper nutrition guidelines together with other 
consumption of heathy foods with improvement of the brain memory. In this topic, Al-Kaheel brings results of the scientific experiments carried out by the German institution to support his view.

\section{Lantern in the Sky}

Surah Fușșilat verse 12:

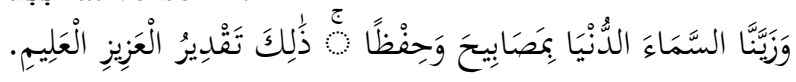

Fușșilat 41:12

And we garnished sky with bright lights flashing and maintain, thus destiny omniscient.

Al-Kaheel explains that the bright and shiny stars mentioned in the Qurān as the 'bright lights' that created to decorate the skies as viewed from the earth. The phenomenon in fact is real as those stars are too bright, which can help guide researchers to investigate celestial stars. In this verse, he elaborated that the stars are too bright even the scientist called it as 'spotlights' which are similar to the analogy used in the Qurān in describing those stars as 'lamps'. However, he did not mention specifically the sources of the scientists and the affiliated institutions.

\section{Orbit of Earth}

Surah Al-Naml verse 88:

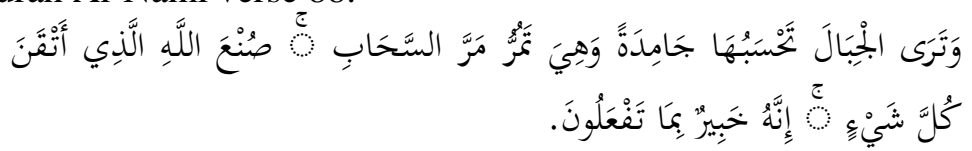

Al-Naml 27:88

And you see the mountains, thinking them rigid, while they will pass as the passing of clouds. [It is] the work of Allah, who perfected all things. Indeed, He is Acquainted with that which you do.

In this verse, Al-Kaheel elaborates on the calculation speed of earth which is faster than the speed of sounds that rotating around the sun which was estimated by the scientist. It was found that tit is faster than 100,000 kilometres per hour. This gives indication that things on the surface of earth is also moving and rotating such as mountains and canyons. However, in commenting this verse, he 
did not also mention specifically the sources of the scientists and the affiliated institutions who carried the research.

\section{Reaching the Age of 40 years}

Surah Al-Ahqaāf verse 15:

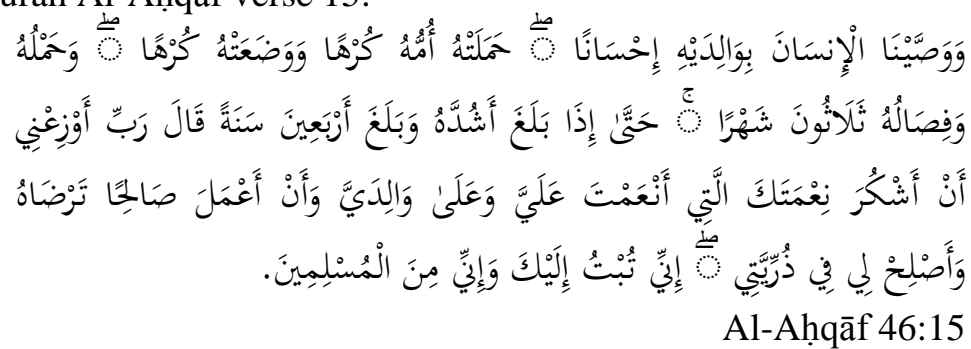

And We have enjoined upon man, to his parents, good treatment. His mother carried him with hardship and gave birth to him with hardship, and his gestation and weaning [period] is thirty months. [He grows] until, when he reaches maturity and reaches [the age of] forty years, he says, "My Lord, enable me to be grateful for Your favour which You have bestowed upon me and upon my parents and to work righteousness of which You will approve and make righteous for me my offspring. Indeed, I have repented to You, and indeed, I am of the Muslims.

In this verse, Al-Kaheel comments that the Prophet (pbuh) was given the Quran as a wahyu 1400 years ago. However, it was discovered in this century that the development of the brain reaches its highest capacity at the age of 40 and afterwards, it reduces slowly. In this verse, again, the scientist who carried out the research and the affiliated institutions were mentioned.

\section{Contribution of Al-Kaheel in the field of learning of the Qurān in the perspective of Modern Science}

Based on Al-Kaheel's articles discussed in various topics and themes through his website, this study highlights contributions and efforts made by him in promoting the learning of the Quran in the perspective of science:

$\circ$ He has received award of Shaykh Salem Al-Ali Al-Sabah for Informatics in 2008 in Kuwait for his contribution in this field.

o Published more than forty books including "Brightening Number Seven in the Holy Quran" which was published to 
commemorate the Dubai International Holy Quran Award in 2006.

- Invited as guest speaker discussing on the miracles of the Quran and scientific interpretation in many TV programs in Arab Countries.

o Presented papers in symposiums and conferences in many countries such as Turkey, Spain, Algeria, Morocco and other Middle East countries.

$\circ$ In his website, there are eleven themes discussed. Every single theme consists of various topics which overall total reach to 783 topics.

$\circ$ His works through his websites are translated into many international languages which means his works already being accessed across all continents and many have benefitted from it.

Through all these efforts and achievements, his works in the area of learning of the Quran in the perspective of science can be considered as tremendous and significant contributions.

\section{Conclusion}

The study found that the objectives of the website cover various areas that promoting the learning of the Qurān in the perspective of modern science. It encourages Muslims to consider this new perspective of learning the Qurān by combining it with the scientific findings so as to be strong evidences that science is one of the important tools to understand verses of the Qurān. However, one should have certain degree of knowledge of Quranic exegesis and science to appreciate the work of the Al-Kaheel. The objectives of the website would be clearly understood if it can provide brief summary or introduction to understand the Qurān in the perspective of science that include the framework and tools.

The study also found that the website provides translations to various languages such as English, French, Persian, Indonesian, Dutch, Turkish, Russian, Kurdish, Japanese, Spanish and Hebrew. This effort has invited more visitors to the website and open up opportunity for Muslims and non-Muslims to read all the articles provided in the website based on the available languages.

With regard to the Quranic learning in the perspective of science, the study found that examples of some topics in the 
website that this study discussed in-line with the criteria framework.

Generally, the scientific findings mentioned in the topics were discovered based on latest technology which is very unlikely to be found in the time of the Prophet pbuh during the revelation of the Qurān. However, some criteria were not consistently used and appeared in all the topics. For instance, the criteria can be clearly identified when discussing on topics such as 'Washing hand as part of cleanliness' and 'Consumption of moderate amount of food increase the memory" Source of references which either scientists or institutions were quoted in both topics. But it was not mentioned in discussing topics on 'Lantern in the sky', 'Orbit of Earth' and 'Reaching the age of 40 years'. Consistency in following the criteria is important as it helps to increase level of credibility of the topics discussed.

There are many positive things to discover when connecting scientific findings with Quranic verses, including the appreciation and in-depth understanding of Quranic verses. The new approach of learning science as supported by the Qurān could be used as material in teaching religion and Quranic interpretation. The purpose of science to strengthen and refine religious creed should be clearer, as one of the main objectives is to strengthen the faith and belief of one who can understand and appreciate verses of the Quran.

Generally, Al-Kaheel has made great efforts of his works in providing topics discussed on verses of the Quran and share his understanding of Quranic verses that discuss the universe, cosmos, heaven and earth, and creation of human beings, through the perspective of modern science. This was done to help one to appreciate the messages of the Qurān to mankind, thus strengthening their faith, belief, and motivation to explore further, using the Internet as a platform. Being able to easily access his research findings online plays a vital role in facilitating the process of learning and understanding the link between the Qurān and modern science.

\section{References}

Abdullah Bukhari. "The Modernisation of teaching Tafsir alQurān among Malays: An Analysis of Development of Data for 
Tafsir al-Qurān”. Academic exercise paper, Academy of Islamic Studies, University of Malaya, 2004.

Abu Bakar Abdul Majeed and Siti Fatimah Abdul Rahman. Multimedia dan Islam. Kuala Lumpur: Institut Kefahaman Islam Malaysia, 2001.

Ahmad Zulfiqar Shah Abdul Hadi. "Sistem Pengajian al-Qurān

Kontemporari: Kajian Aplikasi Teknologi Maklumat dan Komunikasi" (Master's Dissertation, Academy of Islamic Studies, University of Malaya, 2006). 49-50.

Al-Ghazālī, Abū Hāmid Muḥammad bin Muḥammad. Ihyā' 'Ulūm al-Dīn. Cairo: Dār Al-Thaqāfah al-Islāmiyah,n.d..

Baharudin Ahmad. Falsafah Sains dari Perspektif Islam, 2nd ed.. Selangor: Dawama Publication, 2008.

Bucaile, M. "The Quran and the Modern Science" in Mohammad Ilyas, The Unity of Science and Religion (2002), p. 49-68.

Fadhil Haji Othman. Pendidikan Sains dan Teknologi dan Alam Sekitar Menurut Pandangan Islam. Kuala Lumpur: Syeikh Publisher, 1992.

Faizah Mat Juden, Teori kewujudan alam: satu kajian perbandingan di antara sains moden dan al-Qurān. Master;s Dissertation, Academy of Islamic Studies, University Malaya, 2003.

Golshani, Mehdi. The Holy Qurān and the Sciences of Nature. Tehran: Islamic Propagation Organisation, 1986.

Makhdir Mardan. "Mendaki Zaman Perubahan yang berterusan" in Memahami Islam melalui Teknoloji Maklumat dan Komunikasi, ed. Sh. Mohd Saifuddeen Sh. Mohd Salleh. Kuala Lumpur: Institut Kefahaman Islam, 2000.

Muhammad Quraish Shihab. Membumikan al- Quran: Fungsi dan Peran Wahyu dalam Kehidupan Masyarakat. Bandung: Penerbitan Mizan, 1994.

Norharliayana Hamdzani. "Teaching Tafsir Al-Qurān via Internet: Survey on the usage of on-line Tafsir among teachers of Bestari School at Kolej Sultan Alam Shah, Kelang". Academic exercise paper, Faculty of Social Science, Islamic Studies Program, University of Malaya 2001.

Selamat Amir. "Pentafsiran Saintifik dalam Al-Quran: Satu Pengenalan Terhadap Metode Al-Sha'rawī dalam Tafsìr Al- 
Sha 'rawī, Tumpuan Surah Al-An'am ayat 125." Jurnal Usuluddin 42 (2015): 72.

Sidek Baba. "The Muslim Nation Agenda: the Challenges of Information Technology and Internet". Seminar Prosiding, Institut Kefahaman Islam, 1998.

Sirajudin Zar. "Konsep Penciptaan Alam dalam Pemikiran Islam, Sains dan al-Qurān". Master's Dissertation, IAIN Syarif Hidayatullah Jakarta, 1997.

Syed Muhammad Naquib al-Attas. "Keynote address in the International Seminar on Islamic Philosophy and Science USM". Penang: Art Printing Works Sdn. Bhd., 1989.

Syekh Thantāwi Jauhari. Al-Qur'ān dan llmu Pengetahuan Moden, trans. Muhammadiyah Jaafar. Surabaya: Usana Offset Printing, 1984.

Tazli Sham Abd Rahman. "Contrbution of Syakh Abd Al-Majid Al-Zindani to Al-I'jaz Al- 'Ilmi" in Online Journal of Research of Islamic Studies, No.2. (2014) 54-55.

\section{Internet}

Islamic encyclopaedia http://www.islamicencyclopaedia.org/.Retrieved on 12/8/2014.

Qurān and Science, http://quranicsciencesciences.org retrieved on 3/9/2014

Qurānic Science Institute, http://www.qsi1.com/index.asp Retrieved on 10/9/2014.

Easy Qurān, http://www.easyquran.com/ar/prepage-ar.htm Retrieved on 10/9/2014

Qurān Reading http://www.quranreading.com/about-us - Retrieved on 17 September 2014.

Qurān Reading http://www.quranreading.com/about-us - Retrieved on 17 September 2014.

Learning Qurān Online, http://learningquranonline.com/aboutus/ - Retrieved on 17 September 2014

Qurān Translation, http://www.theholyquran.org. - Retrieved on 26/7/2018

At-Tarteel, http://www.tarteel.com http://www.tarteel.com. Retrieved on 26/7/2018

The Royal 'Aal al-Bayt Institute of Islamic Thought, Jordan http://www.altafsir.com- retrieved on 5/4/2014 
Islamic Awareness http://www.islamicawareness.org/Quran/TafseerTafsir/Ulum/ - Retrieved on 26 August 2014.

Islamic Awareness http://www.islamicawareness.org/Quran/TafseerTafsir/Ulum/ - Retrieved on 26 August 2014.

Al-Zindani, Abdel Majed ben Aziz, Ta'sil al-I'jaz al-'Ilmi, http://www.jameataleman.org/mai - Retrieved on 4 May 2015.

Shaykh Ali Jaber, http://www.alijaber.net - Retrieved on 26 July 2018

Qurān website, http://quranwebsite.com - Retrieved on 5 April 2014

Tafsīr Qurān, http://qtafsir.com retrieved on 5 April 2014

At-Tanzīl, http://www.tanzil.net - retrieved on 6 August 2014

Tafsīr Qurān, http://www.tafsir.net - Retrieved on 14 June 2014

Al-Islām, http://www.al-islam.com/arb/ Retrieved on 15 June 2014.

Al-Islām, http://www.al-islam.com/arb/ Retrieved on 15 June 2014.

Waqfeya, http://www.waqfeya.com - Retrieved on 12/8/2014.

Islam Web, http://www.islamweb.net/ - Retrieved on 26/7/2018

The Holy Qurān, http://www.holyquran.net - Retrieved on 26/7/2018

Al-Roqyah, http://www.alroqia.com. - Retrieved on 26 July 2018

The Qurān, http://www.quran.gov.ae/ - Retrieved on 26 July 2018

Islam Way, http://www.islamway.com/- Retrieved on 26 July 2018

Tafsīr, http://www.tafsir.net/- Retrieved on 26 July 2018

Al-Kaheel, http://www.kaheel7.com- Retrieved on 26 July 2018

Al-Kaheel, http://kaheel7.com - Retrieved on 27 July 2018.

Iqrā' Sense, http://www.iqrasense.com- Retrieved on 28 July 2018.

Qurān Complex, http://www.qurancomplex.gov.sa Retrieved on 16 June 2014. 